\title{
Application of Gap Model in Finding Service Quality Gaps: Comparative Study on Domestic and Foreign Banks Operating in Pakistan
}

\author{
Kinza Yousfani ${ }^{1, *}$, Hassan Ali Solangi², Ali Gul Lakhiar ${ }^{2}$ \\ ${ }^{1}$ Department of Management Science, Faculty of Commerce, Economics \& Management Sciences, Isra University, Pakistan \\ ${ }^{2}$ Department of Management Science, Faculty of Sciences and Technology, SZABIST, Pakistan
}

Copyright $\odot 2019$ by authors, all rights reserved. Authors agree that this article remains permanently open access under the terms of the Creative Commons Attribution License 4.0 International License

\begin{abstract}
The banking sector of Pakistan is growing with every passing year and the quality plays a major role in the developed banking sector. To retain loyal customers quality service is vital. Though, quality and customer service are major driving forces in the business community. Moreover, the product's quality is its capability which satisfies customers' expectations and needs. SERVQUAL scale questionnaire is used as research instrument which was developed by Parasuraman et al. (1988) which quantify the expected quality of banking services of selected samples of banks including domestic and foreign banks in Pakistan. The basic aim of this paper is to investigate the service quality and its relationship among domestic and foreign banks operating in Pakistan. A total of 300 respondents (account holders) were surveyed out of which, 50 account holders for each of the 6 banks including domestic and foreign Banks were surveyed. The sample selected is nonrandom convenient sampling method. This study is descriptive as well as comparative. The results, therefore, suggest that Bank Al-Falah has favorable gap scores in terms of Tangibility, Reliability, and Responsibility. Whereas Soneri Bank earned average Gap Scores in Assurance and Empathy. Also, national bank performed as less service quality measure and holding gap scores greater than all the other banks. Hence, therefore, this research indicates that all independent variables tangibility, empathy, reliability, assurance, responsibility, and empathy have significant relationship dependent variables consumer perceive quality. This study offers practical help to researchers and practitioners in providing a direction for service quality improvement by indicating the common theme that develops the service quality model.
\end{abstract}

Keywords SERVQUAL, Tangibility, Reliability, Responsibility, Empathy, Assurance, Perceived Service, Expected Service

\section{Introduction}

Today, it is widely accredited that quality service is a multi-dimensional thought. In Pakistan, the banking sector is growing every year and the quality play major by offering quality services which keep customer loyalty up. Moreover, the quality and customer services are vital driving forces in the business community, also the quality of the product important as it satisfies the expectations and need of the customer. Henceforth banking is the most subtle businesses all around the globe and plays an important role in the economy of Pakistan with no exemption. The sector facilitates and influences to participate in economic activities such as mobilization of resources, elimination of scarcity, and circulation of public finance. Fundamentally, the banking sector of Pakistan comprises of listed commercial banks such as national, foreign and private banks which are regulated by State Bank of Pakistan's (SBP) regulations, Moreover, SBP i.e. central bank of the country and inter alia entrusted with the responsibility for constant supervision of banking sector. Recently, the development of Pakistan's banking sector has shown extraordinary performance. The main purpose of this study is to find the association between customer satisfaction, loyalty and service quality in one frame in the commercial banking sector of Pakistan. This study measures service quality and identifies service quality gaps in Pakistan banking industry using gap model. The sample size of the study is domestic versus foreign banks operating in Pakistan banking sector. The population is the customers of six banks including domestic banks such as National Bank of Pakistan (NBP), Muslim Commercial Bank (MCB), Soneri Bank Limited (SBL) and foreign banks are Standard Chartered Bank (SCB), Bank Al-Falah Limited (BAL) and Dubai Islamic Bank limited (DIBL). The study used an instrument to measure the service quality named as SERVQUAL model and established by Parasuraman et al., (1985), after carrying out the study on 04 service settings 
such as repairs and maintenance of electrical appliance, retail banking, credit card, and long-distance telephone services. SERVQUAL model signifies service quality as a difference between customer perception of the service received and customer expectation of service offering Parasuraman et al., (1985). The model attempts to quantify what accurately consumer perception is when it comes to quality service, it depends on the extent of the gap between the perceived and expected service which in turn depends on the gap under the control of the service provider like marketing or delivery of the service, (Parasuraman et al., 1985). Therefore, the measurement of quality service is based on both factors, how consumer assesses the delivery process of service and its outcome, (Parasuraman et al., 1985). The good service quality is one which exceeds or meet consumer expectation of the service. This study will use the SERVQUAL model for selected domestic and foreign banks operating in Pakistan to see its applicability the measurement of service quality and customer satisfaction. Also, the study aimed to determine perceived service quality by consumers in domestic and foreign banks and to find those dimensions that bring customers satisfaction.

Figure 1: depict external factors that affect customer expectation which can be managed by a quality service provider. The gap in the diagram exhibit different among customer expectation and perception which is called perceived service quality mentioned by Kumar et al., 2009. The author suggests by implementing the SERVQUAL model in the banking gap between customers' perceived service and expectations can easily be identified. The service quality can be measured by five dimensions which are Reliability, Responsiveness, Tangibility, Empathy, and Assurance.

1. Tangibility: It consists of factors like facilities, physical equipment, out of company representative and material. Most of the customer pay more attentive to the above-mentioned factors when they arrived in banks. If the bank environment is not supportive and friendly in dealing with customers than they become irritated and switch towards another bank. The management should focus more on auditory service and physical dimension of the environment in the branches because today customer pays more attention towards these features cited by Malik, 2011. Bank Alfalah and Soneri bank are in leading position intangibles are compared to other banks.

2. Reliability: It is another dimension of quality service. Reliability is how an organization complete service truthfully and consistently. It refers to the ability of the bank to perform the promised service with accuracy and dependability mentioned by Osama \& Ali, in 2009. According to author banks should fulfill the needs of customers that they need and expect from them. Also, reliability can be measured in terms of how accurately handle customer problems, providing accurate services at first cited by Parasuraman et al., 2006. Soneri Bank is one of the leading banks among other comparative banks in providing reliable service.

3. Responsiveness is to provide timely response to the customers' need. It is also known as motivation to facilitate customers and offer timely service suggested by Othman \& Owen in 2013. Responsiveness is a significant factor when online banking comes where customer faces many problems related to the transaction. SBL earn a leading position in responsiveness as they take more responsibility and think customer as its best interest.

4. Assurance: It is the natural fact that polite behavior of employees and their capability to communicate with self-confidence cited by Othman \& Owen in 2013. Assurance is being secure and safe about service was given by the bank to the customer, as they feel satisfied with banks dealing and can trust them. The employees of banks should be well-mannered when communicating with clients. Soneri bank limited assure their customer about quality service by providing the best service during the expected span of time.

5. Empathy: The SERVQUAL model defines empathy as the mean of giving proper attention to the customer and work for the best by understanding their needs. By opting such behavior customer can be retained for a longer period. Bank-Al-Falah shows a hospitable environment to its customers because it needs to achieve more customer loyalty. 


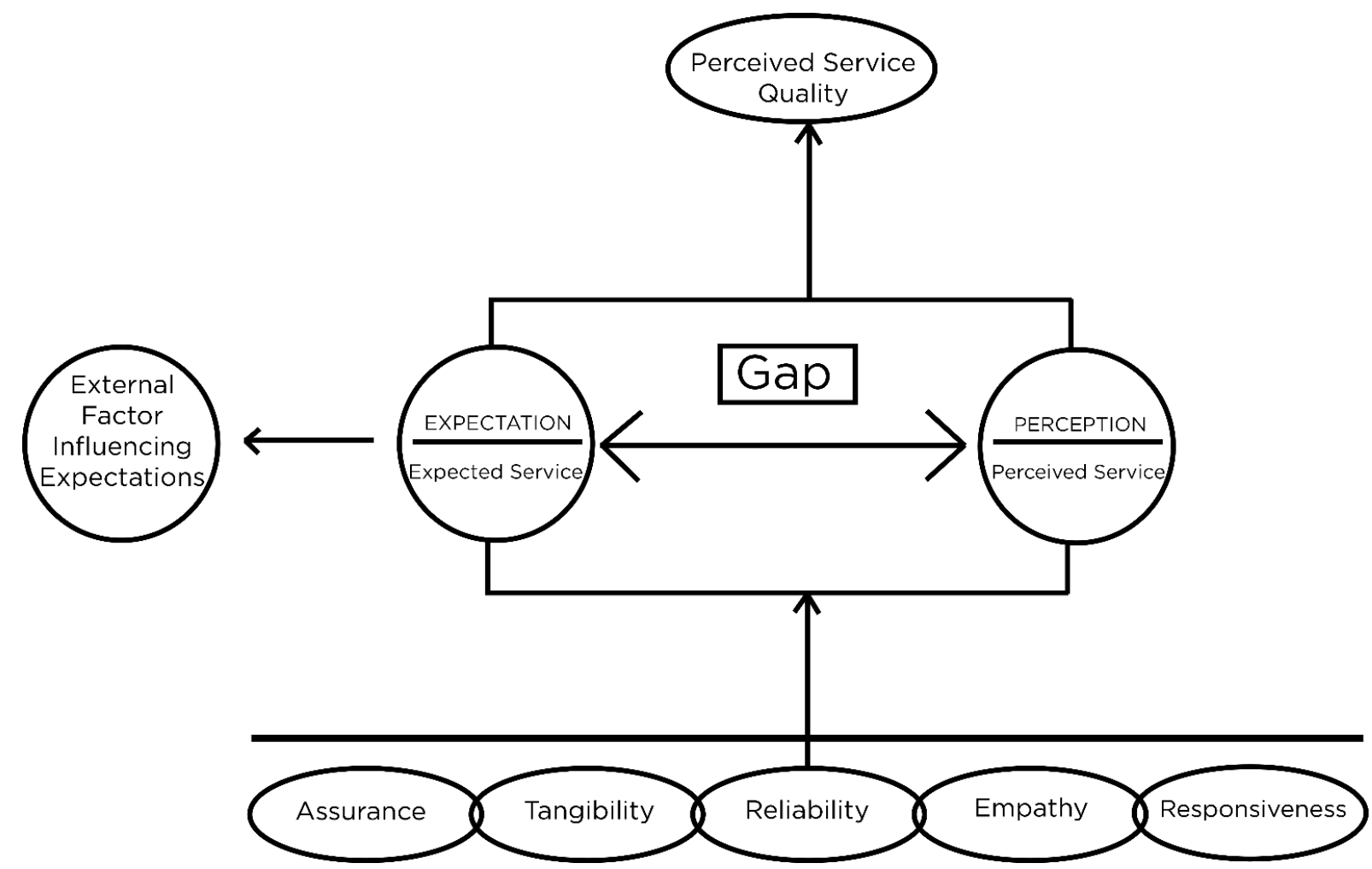

Development of the SERVQUAL Model

Figure 1. Service quality by using SERVQUAL Model (Kumar et al, 2009).

\subsection{Research Questions}

- How consumers perceive service quality in both domestic and foreign banks in Pakistan?

- $\quad$ Are customers (account holders) really satisfied with service quality offered by these banks?

\subsubsection{Hypotheses Development}

- There is a strong relationship between service quality dimensions and consumer perceive quality in both domestic and foreign banks of Pakistan.

- There is a relationship between service quality offered by domestic and foreign banks.

\subsection{The Objective of the Study}

The prime objective of the research work is to analyze and compare the quality service in the Domestic and foreign banks of Pakistan regarding customer perceived and expected service quality. Due to serving competition among banking sector some banks cannot meet customer expectation or perceived quality service. Banking industry plays a major significant role in the economic development and GDP of the country as it is the major source of money circulation and capital market. Therefore, keeping this fact in mind we will measure quality service of domestic and foreign banks by using SERVQUAL model in terms of following five dimensions tangibility, reliability, assurance, empathy, and responsiveness towards customer perceived and expecting quality service.

\subsection{Need for this Study}

Nowadays, globalization and liberalization are disturbing economies not only developing but developed countries also. The major focus of the organization is changing from profit maximization to maximizing profit by increasing customer satisfaction. The competition these days are forcing organizations not to look at the processes but also the way service is delivered. During the past decades, the business scenario has changed drastically. Most of the changes that have taken place in the business are:

- $\quad$ Rapid response to customer need.

- Well-organized and flexible service or product customization.

- Greater importance on organization and process flexibility

- Integrated customer-driven processes

\subsection{Review of Literature}

Quality service is more problematic for the consumer to assess than the quality of the product because of the absence of tangible evidence linked with services. In the early 1920s, the quality thinking initiated with the increase of inspection (Garvin, 1988). Therefore, the empirical and discussion studies related to quality in the late 1950 s where 
the execution of development tools was typically designed to certify the standard level of manufacturing. Furthermore, the development tools were constructed with the aim to eradicate the statistical scrutiny of industrial goods and to keep in mind the customer's opinions, thus to share the accountability of quality to all the employees (Garvin, 1988, Juran, 1992). For this study, only one definition has been chosen that fit the purpose of the study. The definition specified by "Parasurmaman (1985)" that is "Service quality is a comparison of expectations with performance". The authors cited 10 determinants that affect the presence of gap such as access. Courtesy, communication, credibility, reliability, responsiveness, security and understanding the customer and tangibles. For quality service in terms of corporate, physical and interactive quality (Jarmo Lehtinen. 1982), cited that corporate quality states how potential or current customers and public views the service provider. Moreover, physical quality states the tangible characteristics of the service. Similarly, the interactive quality focuses on the interactive nature of the service provider, as well as the customer or representative with both animated and automated interaction. The work is done on the importance of corporate image and experience of service quality play a major role in the service sector (Gronroos, 2001, Lehtinen and Lehtinen, 1982). The customer frequently associates with the same service firm which suggests that their previous experience and perception of service encounter each other. Henceforth the image notion was presented as another additional characteristic. The image influence on customer perception of the firm's communication as well as its operations in many aspects, which makes it satisfactory to have a positive image. If for instance a bank's image either domestic or local, is undesirable, the influence of any mistake will frequently be overstated on the customer's mind. In contrast, a positive image will possibly make the customer ignore minor mistake and manage them. Though the minor mistake happens repeatedly, the image will be spoiled. The supposed quality services as an attitude relating to the superiority of a service or universal judgment cited by (Zeithaml and Bitner, 2003). The grandness of determining quality service assessments has been justifiable in the research literature. Many studies have shown quality service evaluations as closely connected to customer loyalty and positive behavioral intentions (Backman and Veldkamp, 1995; Baker and Crompton, 2000; Bloemer et al., 1999; Zeithaml et al., 1996). According to (Bowen \& Schneider, 1985; Chase \& Bowen, 1991; Kohli \& Jaworski, 1990) delivery of services happens throughout between interaction with employees and customer, also the attitude and behavior of employees can affect customers' insight of quality service. The three factors model such as ambient condition, social factors, and facility design and quality service. These factors define service environments' fundamentals of service delivery process and it best includes as components of the functional dimensions. However, there are some dimensions that are focused and there is no universal agreement on the nature of quality or content cited by (Parasuraman et al, 1985: Gronroos, 2001). The quality service and its five dimensions have a significant association with customer satisfaction and loyalty cited by (Mubbsher et al., 2014). Furthermore, the quality service is an important factor for customer satisfaction and considered as vital tools for banks for enhancing their income and market share mentioned by (Muyeed, 2012). According to (Sobia et al., 2016) all five dimensions of service quality has a significant relationship with customer satisfaction. The six-service quality dimension such as compliance, assurance, responsiveness, tangible, empathy and reliability are a distinct construct. These dimensions have a significant and positive impact over customer satisfaction over Islamic Bank of Pakistan. According to (Mohammad Raza \& Syed Ali Raza., 2017) quality service with six dimensions has suitable reliability, however, each dimension is significant and positively associated with Islamic bank service quality, similarly result mentioned by S.Revathi et al ., 2016.

\subsection{Theoretical Framework}

It is difficult to analyze and access the satisfaction level of intangible assets and one of the major problems organizations nowadays are facing is that they cannot understand the customers' wants and need properly. By now properly receiving perceived and expected quality service customer become dissatisfied, so that bank should make appropriate policies to retain their loyal customers especially in case of service quality quoted by (Munusamy, Chelliah, \& Mun, 2010). The variables of this study are derived from earlier studies discussed in the literature review. The independent variables in this study are the dimension of quality services such as tangibility, assurance, reliability, responsiveness, and empathy. This study finds out the relationship between cause and effect variables by getting customer response on the dimension of quality service and customer perceived and expected quality service which is the dependent variable of this research. 


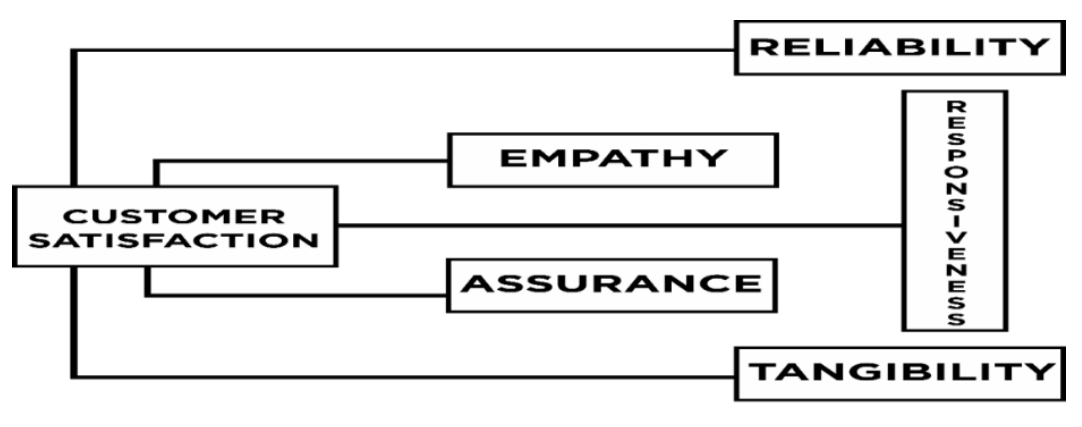

Dimensions of Service Quality

Figure 2. Dimension of Service Quality (Source Authors' construction)

\section{Research Methodology}

This section explains the research methodology of collecting data to address the answers to the research question. First, the research questions are addressed and so the hypotheses have developed. Next, a sampling frame and information collection procedure have been evaluated. Finally, this section draws the validity and reliability test of data. Data for this study has been gathered from the customers from each of the three domestic and three foreign banks operating in Pakistan using SERVQUAL Questionnaire is one of the most widely used research instrument to measure the quality of service (Brown et al., 1996). SERVQUAL measure the gap between customers' expectations for excellence and their perception of actual delivered service. A set of questionnaires distributed to customers of both domestic banks (including NBP, MCB, SBL) and foreign banks (BAL, SCB, DIB) operating in Pakistan. We had personally administered the whole survey. This study will help each of the domestic and foreign banks in Pakistan by providing perceptionexpectation gap scores in identifying deficiencies in service quality about each of 5 dimensions of quality. A total of 300 respondents (account holders) were surveyed out of which, 50 account holders for each of the 6 banks including domestic and foreign Banks were surveyed. The sample selected as a nonrandom convenient sampling method. This study used the SERVQUAL scale questionnaire as research instrument which was developed by Parasuraman et al., (1988) to quantify the predictable and apparent quality of banking services given by selected samples of banks including domestic and foreign banks in Pakistan. The reliability test was conducted and the score of Cronbach's Alpha was 0.93 which reveal the questionnaire reliability to be good. Also, the analysis was carried on the SPSS package and percentage, weighted mean, unweighted average, t-test and ANOVA were the statistical tools adopted in the study. The questionnaire statement was measured on 05 points Likert scale $(5=$ strongly agree and $1=$ strongly disagree).

\subsection{Data Analysis}

The customers' expectation and perception of services to measure service quality in the service sector. This study used the service quality measurement model known as SERVQUAL. The model used the approach for determining quality service which is used to compare customers' expectation before service and their perception of the real service delivered. The SERVQUAL model inventers specify that the customers do not hold quality service attributes in the same respect and are not homogenously significant (Parasuraman, Berry, \& Zeihaml, 1991). Moreover, in the SERVQUAL model, customer perception tool collects respondent input as the importance of each construct by allocating a total of 100 points across many quality service dimensions. The information allows for a measure of salience that can be used to regulate service quality dimensions as most important for customers. Therefore, salience scores are also used to weight the results of SERVQUAL Q scores for each quality service construct by multiplying $Q$ score with salience score attained from the population. Henceforth weighted score delivers bigger insight to the overall importance of quality service construct to survey population. Thus, allowing the service leader to execute more targeted service with improvement. Also, the author mentioned 05 generic dimensions such as:

\subsubsection{Tangibles}

It pertains to personnel and information material, the appearance of physical facilities, modern looking equipment etc. This survey is made on three domestic and three foreign banks.

Table 1. Cross-table of Tangibility dimensions of Sample Banks

\begin{tabular}{|l|c|c|}
\hline BANK NAME & $\begin{array}{c}\text { UNWEIGHTED } \\
\text { AVERAGE }\end{array}$ & $\begin{array}{c}\text { WEIGHTED } \\
\text { AVERAGE }\end{array}$ \\
\hline NBP & 1.98 & 37.50 \\
\hline MCB & 1.25 & 17.20 \\
\hline SBL & 0.85 & 22.30 \\
\hline BAL & 0.84 & 24.58 \\
\hline SCB & 0.95 & 22.15 \\
\hline DIB & 1.16 & 20.40 \\
\hline
\end{tabular}

Interpretation 
In the case of un-weighted average Bank Al-Falah Limited has very much good-looking environment and well equipped according to customers view because it holds 0.84 un-weighted tangible averages. Secondly, customers' viewpoints showed that Soneri bank has also the good-looking environment and physical facilities as it holds 0.85 after Bank Al-Falah limited. Whereas standard chartered bank stood in $3^{\text {rd }}$ position, Dubai Islamic Bank limited holds $4^{\text {th }}$ position, Muslim Commercial Bank in $5^{\text {th }}$ position and National Bank of Pakistan stood in $6^{\text {th }}$ position in terms of physical facilities and equipment as tangible average accordingly. In the case of weighted average customer viewpoints, the most valued score given to Muslim commercial bank according to tangible average which holds 17.20 ( $1^{\mathrm{ST}}$ position). Whereas, DIB, SCB, SBL, BAL, and NBP hold 20.40 ( $2^{\text {nd }}$ position $), 22.15$ ( $3^{\text {RD }}$ position), 22.30 ( $4^{\text {th }}$ position $), 24.58$ ( $5^{\text {th }}$ position) and 37.50 ( $6^{\text {th }}$ position) respectively.

\subsubsection{Reliability}

The capability to perform assured service to the customer correctly and fairly.

Table 2. SERVQUAL model Cross table based on the reliability dimension

\begin{tabular}{|l|c|c|}
\hline $\begin{array}{l}\text { BANK } \\
\text { NAME }\end{array}$ & $\begin{array}{c}\text { UNWEIGHTED } \\
\text { AVERAGE }\end{array}$ & $\begin{array}{c}\text { WEIGHTED } \\
\text { AVERAGE }\end{array}$ \\
\hline NBP & 2.038 & 43.395 \\
\hline MCB & 1.176 & 23.006 \\
\hline SBL & 0.894 & 22.235 \\
\hline BAL & 1.008 & 20.308 \\
\hline SCB & 1.179 & 30.694 \\
\hline DIB & 1.243 & 24.59 \\
\hline
\end{tabular}

Interpretation

In the case of un-weighted average Soneri Bank limited provides a very reliable service to its customers have good faith in it because it holds 0.894 reliability averages and stood in $1^{\text {st }}$ position. Whereas Bank Al-Falah stood $2^{\text {nd }}$ position and holds a 1.008 average reliability score, Muslim Commercial Bank stood $3^{\text {rd }}$ position and holds a 1.176 average reliability score, Standard Chartered Bank stood $4^{\text {th }}$ position and holds 1.179 average reliability score, Dubai Islamic bank stood in $5^{\text {th }}$ position and holds 1.243 average reliability score and National Bank of Pakistan stood $6^{\text {th }}$ position which holds 2.038 average reliability score according to reliable service providence to its customers. In the case of weighted average customer view, the most valued score according to reliability holds Bank Al-Falah 20.308. Whereas, Soneri Bank Limited 22.235, Muslim Commercial Bank 23.006, Dubai Islamic Bank 24.59, standard chartered bank 30.694 and National bank of Pakistan 43.395 holds $2^{\text {nd }}, 3^{\text {rd }}, 4^{\text {th }}, 5^{\text {th }}$, and $6^{\text {th }}$ position respectively.

\subsubsection{Responsiveness}

To help in customer nature and desire to deliver them quick service that makes up the dimension of responsiveness. Parasuraman, et al., (1991) exemplify components in responsiveness and express client precise time duration among those services are done, punctuality of service, disposition to be of help, also too busy to respond to client requests.

Table 3. Cross Table on customer service dimension towards responsiveness

\begin{tabular}{|l|c|c|}
\hline $\begin{array}{l}\text { BANK } \\
\text { NAME }\end{array}$ & $\begin{array}{c}\text { UNWEIGHTED } \\
\text { AVERAGE }\end{array}$ & $\begin{array}{c}\text { WEIGHTED } \\
\text { AVERAGE }\end{array}$ \\
\hline NBP & 2.068 & 51.41 \\
\hline MCB & 1.225 & 29.365 \\
\hline SBL & 1.079 & 25.88 \\
\hline BAL & 1.0892 & 22.44 \\
\hline SCB & 1.209 & 27.525 \\
\hline DIB & 1.26 & 24.955 \\
\hline
\end{tabular}

Interpretation

In the case of un-weighted average, SBL takes more responsibility and think customers as its best interest because it holds 1.079 responsibility averages. Whereas, BAF, SCB, DIB, MCB, and NBP holds 1.0892, 1.209, 1.26, 1.225 and 2.068 as responsibility average respectively. In the case of weighted average customer view, the most valued score according to responsibility holds BAF 22.44. Whereas Dubai Islamic Bank holds 24.955, SBL holds 25.88, SCB holds 27.525, MCB holds 29.365 and NBP holds 51.41 average responsibility scores and stood $2^{\text {nd }}, 3^{\text {rd }}$, $4^{\text {th }}, 5^{\text {th }}$, and $6^{\text {th }}$ position respectively.

\subsubsection{Assurance}

Parasuraman, et al (1991) enclosed actions by workers like continuously well-mannered behavior inspires self-confidence and information as major components of assurance. The substitute's competency, courtesy, quality, and security within the original 10 dimensions for evaluating service quality (Zeithaml, et al, 1988).

Table 4. Cross Table on Customer Service Assurance by banks

\begin{tabular}{|l|c|c|}
\hline $\begin{array}{l}\text { BANK } \\
\text { NAME }\end{array}$ & $\begin{array}{c}\text { UNWEIGHTED } \\
\text { AVERAGE }\end{array}$ & $\begin{array}{c}\text { WEIGHTED } \\
\text { AVERAGE }\end{array}$ \\
\hline NBP & 2.017 & 39.905 \\
\hline MCB & 1.244 & 25.115 \\
\hline SBL & 0.86 & 15.735 \\
\hline BAL & 1.084 & 17.169 \\
\hline SCB & 1.185 & 24.75 \\
\hline DIB & 1.258 & 24.83 \\
\hline
\end{tabular}

\section{Interpretation}

In the case of un-weighted average SBL best assure their customers by providing service during their expected span of time because it holds 0.86 assurance averages. Whereas BAF holds 1.084, SCB holds 1.185, Muslim commercial 
bank holds 1.244, DIB holds 1.258 and NBP holds 2.017 as assurance averages accordingly. In the case of weighted average customer view the most valued score according to the assurance given to SBL because it holds 15.735 average assurance score. Whereas BAF holds 17.169, SCB holds 24.75, DIB holds 24.83, MCB holds 25.115 and NBP holds 39.905 as average assurance scores and stood $2^{\text {nd }}, 3^{\text {rd }}, 4^{\text {th }}$, $5^{\text {th }}$, and $6^{\text {th }}$ position respectively.

\subsubsection{Empathy}

Empathy is kind as well customized consideration organization offers to its customers. Individual care and suitable operational hours are two main components enclosed by Parasuraman, et al., (1991) in their analysis of sympathy.

Table 5. Cross Table on hospitability atmosphere by banks to customers

\begin{tabular}{|l|c|c|}
\hline $\begin{array}{l}\text { BANK } \\
\text { NAME }\end{array}$ & $\begin{array}{c}\text { UNWEIGHTED } \\
\text { AVERAGE }\end{array}$ & $\begin{array}{c}\text { WEIGHTED } \\
\text { AVERAGE }\end{array}$ \\
\hline NBP & 2.314 & 42.564 \\
\hline MCB & 1.395 & 27.506 \\
\hline SBL & 1.178 & 24.37 \\
\hline BAL & 1.172 & 27.192 \\
\hline SCB & 1.497 & 28.12 \\
\hline DIB & 1.321 & 25.92 \\
\hline
\end{tabular}

\section{Interpretation}

In the case of un-weighted average Bank-Al-Falah shows a hospitable environment to its customers because it needs to achieve more customer loyalty and holds 1.172 empathy averages. Whereas SBL stood $2^{\text {nd }}$ position by holding 1.178 empathy averages, DIB stood $3^{\text {rd }}$ position as it holds 1.321 empathy averages, MCB stood $4^{\text {th }}$ position by holding 1.395 , SCB stood $5^{\text {th }}$ position by holding 1.497 average empathy score and NBP stood $6^{\text {th }}$ position which holds 2.314 average empathy score. In case of weighted average customer view the most valued score given to SBL as it holds 24.37 average sympathy score, whereas DIB, BAL, MCB, SCB, and NBP stood $2^{\text {nd }}, 3^{\text {rd }}, 4^{\text {th }}, 5^{\text {th }}$, and $6^{\text {th }}$ position by holding 25.92, 27.192, 27.506, 28.12 and 42.564 as average empathy scores respectively. 2.12 . Interpretation

Measuring overall performance, SBP is providing best customer desired services and achieve extensive customers' delighters as it secures 1.1014 Average Un-Weighted SERVQUAL score. Whereas, Bank Al-Falah stood at the $2^{\text {nd }}$ position after Soneri bank in overall performance measurement but the other four branches don't have that much score. They all are needed to improve service quality due to having the same level in terms of performance. Their service providers don't pay much attention to their customers' interest as compare to that of two banks (SBL and BAL). Similarly, NBP of Pakistan being a large working group in Pakistan's Banking sector should consider the customers as a part of it's for enabling good service quality.

Table 6. Comparison of unweighted Average SERVQUAL Scores on total banks

\begin{tabular}{|l|c|}
\hline BANK NAME & UNWEIGHTED AVERAGE \\
\hline NBP & 2.2422 \\
\hline MCB & 1.6992 \\
\hline SBL & 1.1014 \\
\hline BAL & 1.14468 \\
\hline SCB & 1.282 \\
\hline DIB & 1.2754 \\
\hline
\end{tabular}

Table 7. Comparison of weighted average SERVQUAL scores on total banks

\begin{tabular}{|l|c|}
\hline BANK NAME & WEIGHTED AVERAGE \\
\hline NB & 42.9528 \\
\hline MCB & 25.7634 \\
\hline SBL & 22.161 \\
\hline BAL & 21.314 \\
\hline SCB & 25.8952 \\
\hline DIB & 25.4258 \\
\hline
\end{tabular}

\section{Interpretation}

BAL secured 21.314 and stood in $1^{\text {st }}$ position in terms of quality of services. Whereas SBL secured $2^{\text {nd }}$ position and holds 22.161. Here is the same way other four banks need to be improved their quality of services to providing the same quality service to their customers. By this way, customer loyalty cannot be achieved for the remaining four banks including DIB, SCB, MCB, and NBP. 2.14. Interpretation

In the above table, dimension wise gap score is calculated and presented which shows that Bank Al-Falah has favorable gap scores in terms of Tangibility, Reliability, and Responsibility because it holds a comparatively little number as that of remaining two dimensions. Whereas in case of Assurance and Empathy average Gap scores. Soneri Bank is showing favorable results as can be seen in the table. We can easily examine that National Bank of Pakistan is a large working group and national bank of the country is having less service quality measure and holding gap scores greater than all the other banks. 
Table 8. Weight Comparison of Banks on Customer Service Dimensions

\begin{tabular}{|l|c|c|c|c|c|}
\hline BANKS/DIMENSIONS & $\begin{array}{c}\text { Average } \\
\text { Tangible Score }\end{array}$ & $\begin{array}{c}\text { Average } \\
\text { Reliability } \\
\text { Score }\end{array}$ & $\begin{array}{c}\text { Average } \\
\text { Responsiveness } \\
\text { Score }\end{array}$ & $\begin{array}{c}\text { Average } \\
\text { Assurance Score }\end{array}$ & $\begin{array}{c}\text { Average } \\
\text { Empathy Score }\end{array}$ \\
\hline National Bank of Pakistan & 37.49 & 43.395 & 51.41 & 39.905 & 42.564 \\
\hline Standard Chartered Bank & 22.15 & 30.694 & 27.525 & 24.75 & 28.12 \\
\hline Muslim Commercial Bank & 24.58 & 23.006 & 29.365 & 25.115 & 27.506 \\
\hline Soneri Bank Limited & 22.295 & 22.235 & 25.88 & 15.735 & 24.37 \\
\hline Bank Al-Falah Limited & 17.194 & 20.308 & 22.44 & 17.169 & 27.192 \\
\hline Dubai Islamic Bank Limited & 20.403 & 24.59 & 24.955 & 24.83 & 25.92 \\
\hline
\end{tabular}

\section{Conclusions}

The quality service is unpredictable between customers' expectations for offering service as well as customers perception for service received and requiring respondents to answers the question about their perception and expectation (Parasuraman, 1988). SERVQUAL assist as a diagnostic procedure for finding widespread areas of an organization's quality service weaknesses and strengths. The tool produces an organized, interactive and multi-stage process that progresses from the known dimensions and items within that correspond to the specific companies and industries (Zeithaml, 1988). Also, this tool is considered for use any kind of business providing service business and basic skeleton through its expectations or perceptions format, surrounding statement for each of the five dimensions (Parasuraman,1988). The items of the scale were then pre-tested for wording, design, and comprehension. The results, therefore, suggest that Bank Al-Falah has favorable gap scores in terms of Tangibility, Reliability, and Responsibility. Whereas Soneri Bank earned average Gap Scores in Assurance and Empathy. Also, national bank performed as less service quality measure and holding gap scores greater than all the other banks. Therefore, this study concludes that all independent variables such as tangibility, empathy, reliability, assurance, responsibility, and empathy have significant relationship dependent variables consumer perceive quality. Also, the study shows the relationship between service quality offered by foreign and domestic banks. In Pakistan banking staff rarely pay attention to prompt quality service and the customer must way for long hours to be facilitative. Furthermore, customers are more concerned about the aspect of service.

\section{REFERENCES}

[1] Brady M.K., Cronin, J.J. Jr, (2001), 'Some new thoughts on conceptualizing perceived service quality, Journal of Marketing, Vol. 56, pp .55-68

[2] Brown, S. W., \& Swartz, T. A. (1996). A gap analysis of professional service quality. The Journal of Marketing, pp.
92-98.

[3] Bowen, D. E., \& Schneider, B. (1985). Boundary-spanning-role employees and the service encounter: Some guidelines for management and research. The service encounter, pp. 127, 148.

[4] Buttle, F. (1996). SERVQUAL: review, critique, research agenda. European Journal of marketing, Vol 30(1), pp. $8-32$.

[5] Backman, S. J., \& Veldkamp, C. (1995). Examination of the relationship between service quality and user loyalty. Journal of Park and Recreation Administration, Vol. 13(2), pp. 29-41.

[6] Baker, D. A., \& Crompton, J. L. (2000). Quality, satisfaction, and behavioral intentions. Annals of tourism research, Vol. 27(3), pp. 785-804.Bloemer, J., Ko de Ruyter, \& Wetzels, M. (1999). Linking perceived service quality andservice loyalty: A multi-dimensional perspective. Journal of Marketing, vol. 33, pp.1082-1106.

[7] Chase, R. B., \& Bowen, D. E. (1991). Service quality and the service delivery system: A diagnostic framework. SW Brown, E. Gummesson, B. Edvartsson, B. and B. Gustavsson (eds.). System Quality-Multidisciplinary and Multinational Perspectives. New York, NY: Lexington Books.

[8] Garvin, D. A. (1988). Managing quality: The strategic and competitive edge. Simon and Schuster.

[9] Grönroos, C. (2001). Service marketing and management. A customer relationship management approach. European Business Review, 20(4), pp. 298-314.

[10] Juran, J. M. (1992). Juran on quality by design: the new steps for planning quality into goods and services. Simon and Schuster.

[11] Kohli, A. K., \& Jaworski, B. J. (1990). Market orientation: the construct, research propositions, and managerial implications. The Journal of Marketing, pp. 1-18.

[12] Kumar, M., Kee, F. T. \&Manshor, A. T. (2009). Determining the relative importance of critical factors in delivering service quality of banks; An application of dominance analysis in the SERVQUAL model, Managing Service Quality, Vol. 19, Number 2, p.211-228.

[13] Lehtinen, U., \& Lehtinen, J. R. (1982). Service quality: a study of quality dimensions. Service Management Institute.

[14] Munusamy, J., Chelliah, S., \& Mun, H. W. (2010). Service 
quality delivery and its impact on customer satisfaction in the banking sector Malaysia. International journal of innovation, management, and technology 4.

[15] Malik, P. (2011). Impact of perceived service quality on banking customers ' loyalty. Interdisciplinary Journal of Contemporary Research in Business, Vol 8.

[16] Muyeed, M. A. (2012). Customer Perception of Service Quality in Retail Banking in Developing Countries-A Case Study. International Journal of Marketing Studies, 4(1), pp.116-122.

[17] Ali, M., \& Raza, S. A. (2017). Service quality perception and customer satisfaction in Islamic banks of Pakistan: the modified SERVQUAL model. Total Quality Management \& Business Excellence, 28(5-6), pp. 559-577.

[18] Osman, I., Ali, H., Zainuddin, A., Wan Rashid, W. E., \& Jusoff, K. (2009). Customers Satisfaction in Malaysian Islamic Banking. International Journal of Economics and Finance, 1.

[19] Parasuraman, A., Zenithal, V.A., and Berry, L.L. (1985), “A conceptual model of service quality and its implications for future search", Journal of Marketing, Vol. 49, Fall, pp. $41-50$

[20] Parasuraman, A., Valarie A. Zeithaml, and Leonard L. and Berry (1991), 'An Empirical Examination of Relationships in an Extended Service Quality Model', Marketing Science Institute, Cambridge, MA.

[21] REVATHI, S. (2016). Dimensions of Service Quality and Customer Satisfaction: Banking Sector.

[22] Tufail, H. S., Hmayon, A. A., Javed, I., Shabbir, M., \& Shahid, A. U. (2016). Measuring Service Quality in the Banking Sector of Bahawalpur, Pakistan. The Journal of Commerce, 8(1-2), 1.

[23] Wilson, A., Zeithaml, V. A., Bitner, M. J., \& Gremler, D. D. (2012). Services marketing: Integrating customer focus across the firm (No. 2nd Eu). McGraw Hill.

[24] Zeithaml, V. A., Berry, L. L., \& Parasuraman, A. (1996). The behavioral consequences of service quality. the Journal of Marketing, pp. 31-46. 